\title{
ANALYSIS OF HYDROLOGY AND WATER ALLOCATION WITH SWAT AND MIKE HYDRO BASIN IN THE SABOR RIVER BASIN, PORTUGAL
}

\author{
REGINA SANTOS, LUÍS SANCHES FERNANDES, RUI CORTES \& FERNANDO PACHECO \\ University of Trás-os-Montes and Alto Douro, Portugal
}

\begin{abstract}
Hydrological modelling is an important tool for the detailed evaluation of hydrological processes, allowing the analysis of the consequences of current management practices and the prediction of the impact of medium- and long-term agricultural and demographic projections. The present study intends to analyze the water management practices and demographic evolution of the Sabor River basin between 1960 and 2009, and to evaluate the medium- and long-term impact of agricultural and demographic projections. To that end, we used two separate software packages to fulfill the proposed goal, SWAT and MIKE HYDRO Basin. This SWAT was used in the construction of the hydrological model and MIKE HYDRO Basin in the simulation of water allocation, namely irrigation and domestic consumption. Primary results indicate that the low population density recorded in the basin area between 1960 and 2009 was negligible and had no significant impact on the flow. However, as the agricultural area occupies $59 \%$ of the basin, the water consumption for irrigation represented, on average, $27 \%$ of the streamflow.
\end{abstract}

Keywords: SWAT, MIKE HYDRO Basin, hydrological modelling, demographic projections, irrigation.

\section{INTRODUCTION}

The changes in land use and demography form an important component of environmental change. The human interference in the quantity and quality of water resources is significant enough today to be defined as a function of the management of the land use practiced in the river basin. These changes in a hydrographic basin can have significant impacts on runoff and on the concentration of sediments and nutrients in water. This approach enables the evaluation of various water uses and aspects related to the land use. The hydrological modelling is an important tool to evaluate the hydrological processes in detail, allowing, on the one hand, to analyze the consequences of current management practices, and on the other, to predict the impact of environmental and demographic projections in the medium and long term.

The SWAT (Soil and Water Assessment Tool) software was the hydrological model used to model the physical processes that occurred in the Sabor River basin. This software is based on a mathematical model developed by the United States Department of Agriculture (USDA) [1], [2]. This software was selected because it is a physical model that requires the introduction of a series of spatio-temporal data, to predict the impact of human interventions (e. g. changes in agriculture practices and the addition of chemical fertilizers) in hydrological and chemical processes in river basins [3], [4]. The MIKE HYDRO Basin is software developed by the Danish Hydrologic Institute [5] and is used as a decision support tool for integrated water resources management and planning. This software provides comprehensive hydrological modelling to provide basin-scale solutions. It is used to manage water distribution in a basin which includes reservoir and hydroelectric operations, as well as water quality problems [6], [7]. In this study, MIKE HYDRO Basin was selected to create the water allocation model for irrigation and domestic consumption. The objective of this study is to evaluate the impacts of water management practices and demographic trend in the Sabor 
River basin as well as to estimate the effects of medium and long-term changes of the demographic projection in the water allocation for domestic consumption and agriculture.

\section{MATERIALS AND METHODS}

\subsection{Study area}

The Sabor River is located in northeast Portugal and is a tributary of the Douro River. The main watercourse is $212.6 \mathrm{~km}$ long and the area of catchment is approximately $3834.5 \mathrm{~km}^{2}$ (3170 km² Portuguese part) (Fig. 1). The meteorological data for the basin from 1960 and 1999 shows an annual average rainfall of $745 \mathrm{~mm}, 565 \mathrm{~mm}$ of evapotranspiration and $151 \mathrm{~mm}$ of surface runoff respectively. The data based on Corine Land Cover 1990 [8] demonstrates that agriculture occupies $59 \%$ of the basin area, whereas $31 \%$ is occupied by semi-natural areas and $9 \%$ of the basin is covered is forested area. The final $1 \%$ is covered by artificial areas and water bodies.

\subsection{SWAT and MIKE HYDRO Basin models and input data}

In SWAT, the Sabor River basin model was divided into 37 sub-basins. Subsequently, the digital elevation model [8], soil type, Corine land cover [9], meteorological and hydrological

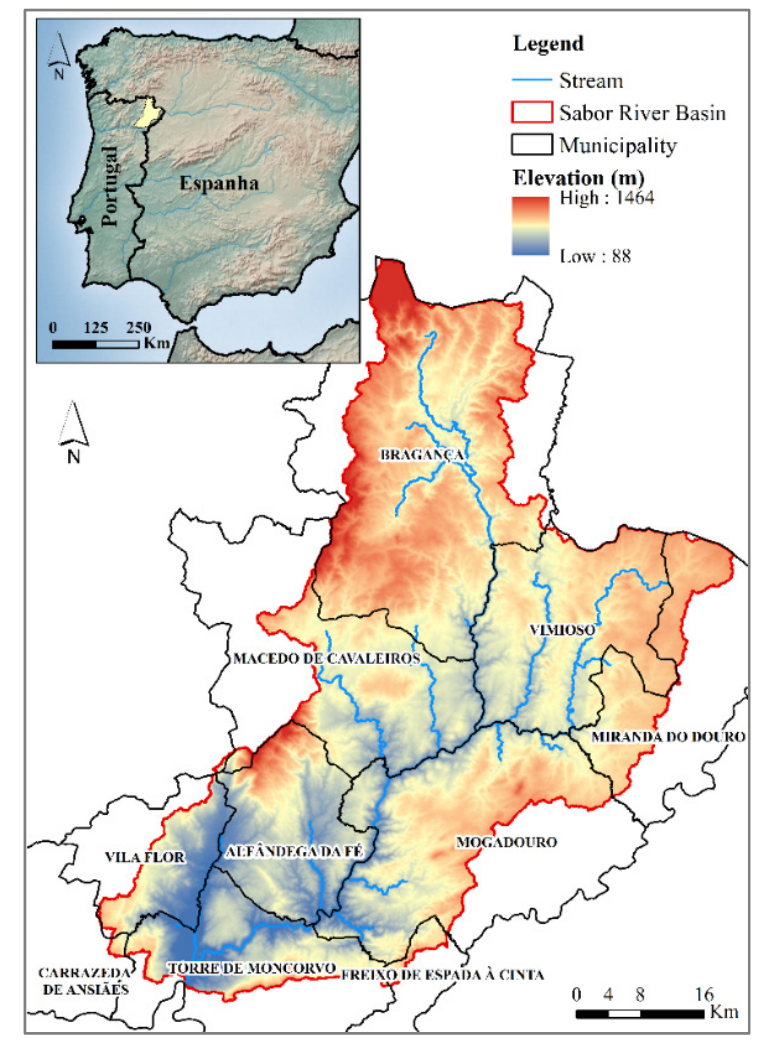

Figure 1: Geographical location, topography, drainage network and administrative limits of Sabor River basin, Portugal. 
data [10] were added between 1960 and 2009. The streamflow obtained in the SWAT model were subsequently inserted in the MIKE HYDRO Basin to model the uses of water, namely domestic consumption and irrigation. Domestic consumption was calculated with population density and water consumption per capita data between 1960 and 2009 [11], [12]. The population in the municipalities, covered by the Sabor River basin, declined by $47 \%$ between 1960 and 2011 (Table 1). The average population density recorded in the 2011 census was 19 inhabitants $/ \mathrm{km}^{2}$ and the average domestic water consumption per capita was 50 liters/day. Fig. 2 represents the population density by municipality (example year 2005). The amount of water used in irrigation was calculated based on irrigated crops and agricultural areas identified in the land use and land cover of 2007 [9], and on the characteristics of each crop from the full form of FAO tables [13]. The crops defined for irrigation were: olives, forages, fruit trees, vineyards, maize, potatoes and vegetables and legumes. The olives represent the crop with the largest area, about $322 \mathrm{~km}^{2}$ (Table 2), distributed in the center and south of the Sabor River basin (Fig. 2).

The projection of water allocation in the river basin was estimated for 2060. By 2060, it is expected that the population will decrease by $24 \%$ [11]. The objective is to know the consequences of the population decrease in the water allocation at the basin, this is because in the last decades the decrease of the population has led to the decrease of the irrigable area at the basin [11], [14]. In Portugal between 1989 and 2009 there was a decrease of 350,000 ha of irrigable area, which represented a reduction of 39\% [15]. Therefore, it is expected that irrigable area and water used in agriculture will decrease continuously. In this way, the projection for 2060 estimates the reduction of $71 \%$ of irrigable area.

Table 1: Population density and domestic water consumption for each municipality in the Sabor River basin.

\begin{tabular}{|l|c|c|c|c|}
\hline \multirow{2}{*}{ Municipality } & \multicolumn{4}{|c|}{ Population density } \\
\cline { 2 - 5 } & $\begin{array}{c}\text { Resident } \\
\text { population } \\
(2011)\end{array}$ & $\begin{array}{c}\text { Variation of } \\
\text { population } \\
(1960-2011) \\
(\%)\end{array}$ & $\begin{array}{c}\text { Population } \\
\text { density }(2011) \\
\text { inhabitants } \\
\left./ \mathrm{km}^{2}\right)\end{array}$ & $\begin{array}{c}\text { Domestic water } \\
\text { consumption per } \\
\text { capita (liters/day) } \\
(1995-2009)\end{array}$ \\
\hline Alfândega da Fé & 5,104 & -47 & 16 & 43 \\
\hline Bragança & 35,341 & -6 & 30 & 44 \\
\hline Carrazeda de Ansiães & 6,373 & -56 & 23 & 45 \\
\hline Freixo de Espada à Cinta & 3,780 & -48 & 15 & 55 \\
\hline Macedo de Cavaleiros & 15,776 & -40 & 23 & 47 \\
\hline Miranda do Douro & 7,482 & -61 & 15 & 39 \\
\hline Mogadouro & 9,542 & -51 & 13 & 74 \\
\hline Torre de Moncorvo & 8,572 & -54 & 16 & 54 \\
\hline Vila Flor & 6,697 & -43 & 25 & 43 \\
\hline Vimioso & 4,669 & -63 & 10 & 55 \\
\hline Total & 10,334 & -47 & 19 & 50 \\
\hline
\end{tabular}




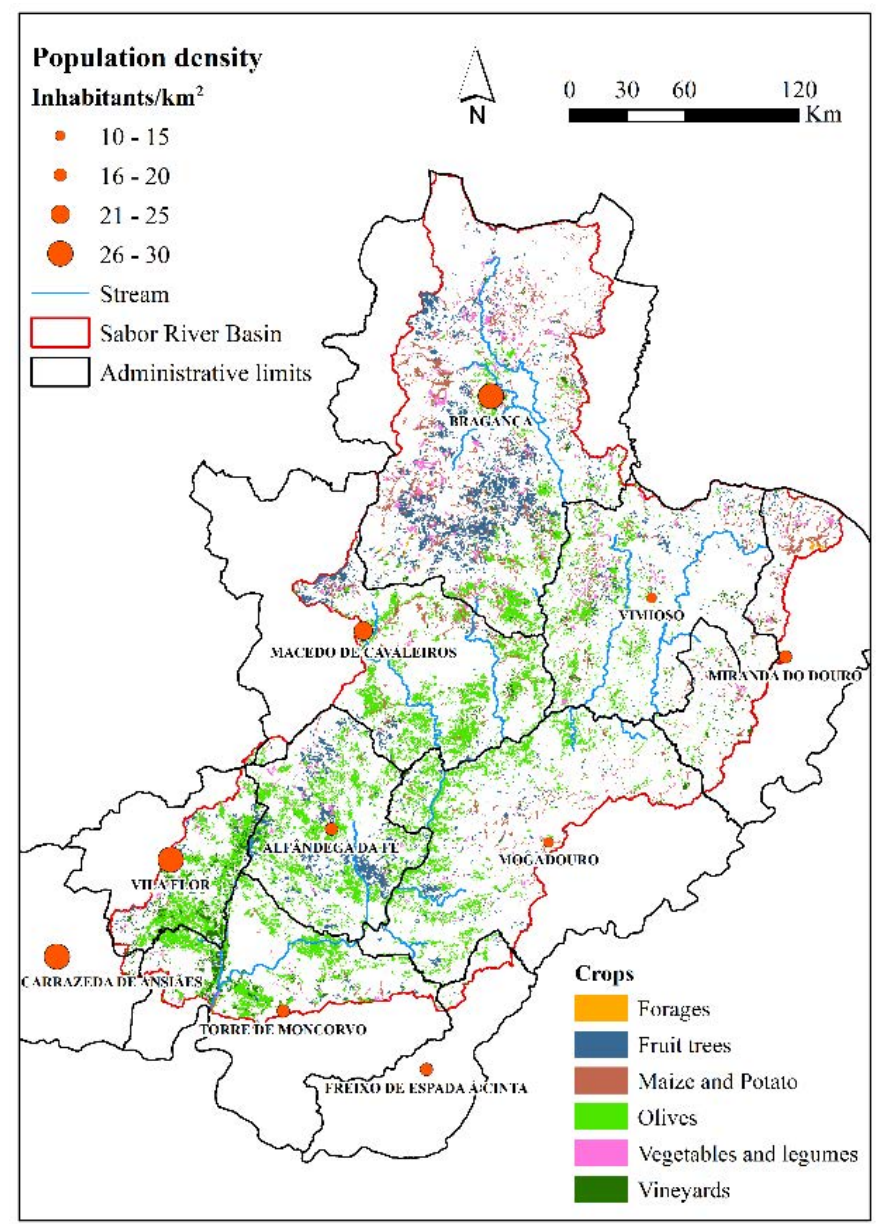

Figure 2: Population density per municipality and irrigated crops in the Sabor River basin.

Table 2: The crops defined for irrigation and respective mean, maximum and total area occupied in the Sabor River basin.

\begin{tabular}{|l|c|c|c|}
\hline \multirow{2}{*}{ Basin } & \multicolumn{3}{|c|}{ Irrigated area $\left(\mathrm{km}^{2}\right)$} \\
\cline { 2 - 4 } & Mean & Maximum & Total \\
\hline Forages & 0.05 & 0.90 & 1.84 \\
\hline Fruit trees & 3.53 & 16.40 & 130.78 \\
\hline Maize & 0.77 & 2.89 & 28.54 \\
\hline Olives & 8.70 & 54.04 & 321.85 \\
\hline Potato & 0.77 & 2.89 & 14.27 \\
\hline Vegetables and legumes & 0.86 & 3.76 & 31.85 \\
\hline Vineyards & 1.17 & 9.42 & 43.37 \\
\hline
\end{tabular}




\section{RESULTS AND DISCUSSION}

The SWAT was used to delineate the 37 sub-basins, create the drainage network and build the hydrological model. The hydrological model was constructed to simulate the components of the water balance for each sub-basin of the Sabor River. The sub-basins, the drainage network and the results in the hydrological model, namely the surface flow and groundwater recharge were inserted in MIKE HYDRO Basin. In MIKE HYDRO Basin, water user and irrigation user icons were also added per sub-basin to model the water allocation in the basin (Fig. 3).

Following the simulation of water allocation (for irrigation and domestic consumption) using MIKE HYDRO Basin, the simulated streamflow model was compared to the observed streamflow of the river. Results of this comparison, i.e. the hydrograph demonstrates low correlation between the simulated and observed streamflow (Fig. 4(a)). This correlation is low because the data simulated by the SWAT were not calibrated. The calibration was not done because it is intended to use both the SWAT and the MHB. The SWAT was used to

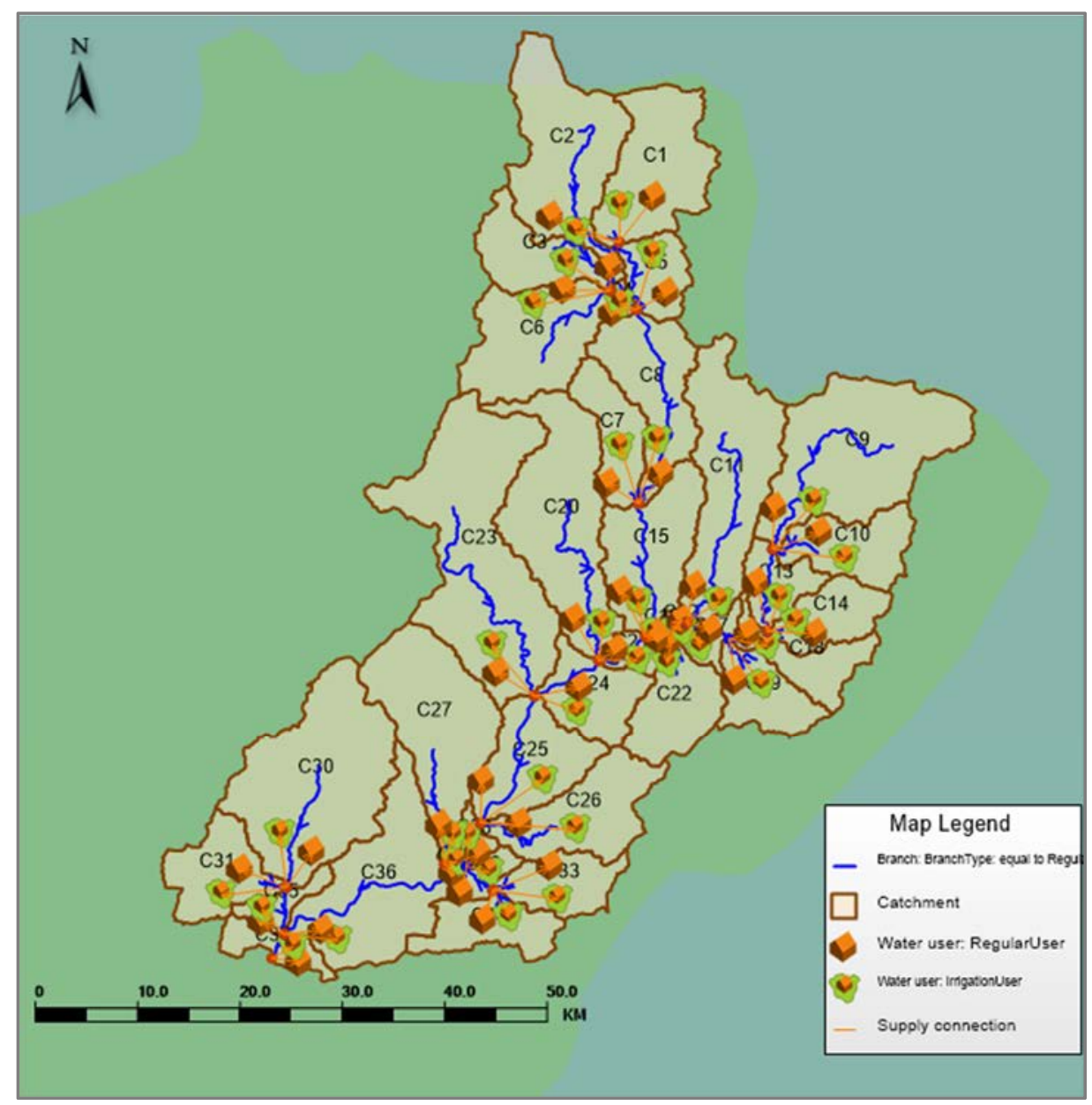

Figure 3: Layout of MIKE HYDRO Basin with drainage network, water user and irrigation user at sub-basin scale. 
construct the hydrological model and MIKE HYDRO Basin was used to simulate the water used for domestic consumption and for irrigation. The hydrological model cannot be calibrated in the SWAT because the observed streamflow used in calibration includes the water that was used for domestic consumption and irrigation. However, the dispersion plot of the simulated vs observed streamflow showed a good coefficient of determination (0.7) (Fig. 4(b)).
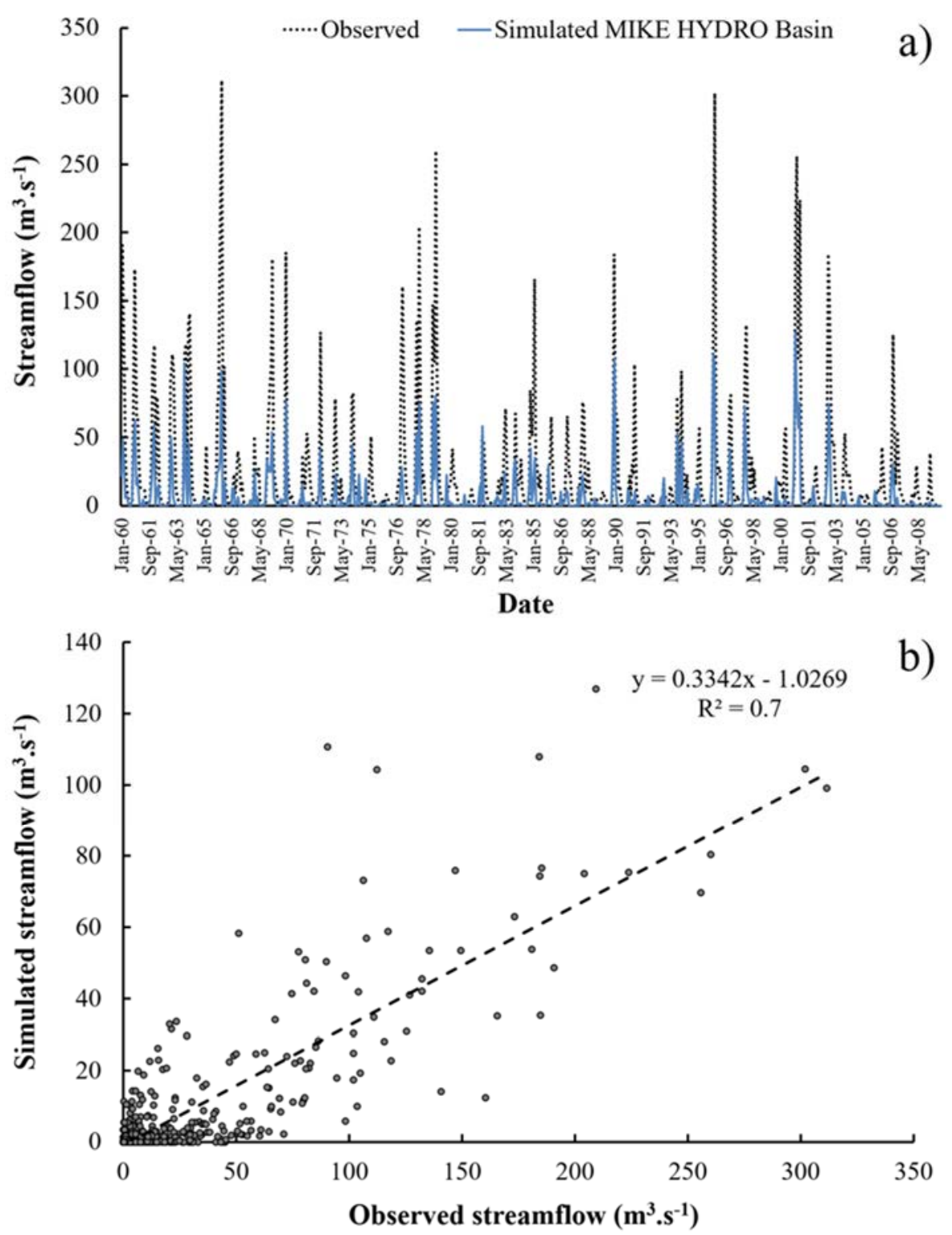

Figure 4: (a) Monthly observed and simulated streamflow temporal evolution by MIKE HYDRO Basin; (b) Dispersion plot of simulated versus observed monthly streamflow in the Sabor River Basin for the 1960-2009 period. 
Figs 5(a)-(c) show the average values of streamflow and water used for domestic consumption and for irrigation between 1960 and 2009. The values are represented at the sub-basin scale and presented the following variations: streamflow varied between 0.11 and $3.91 \mathrm{~m}^{3} / \mathrm{s}$, the water used for domestic consumption varied between 0.001 and $0.004 \mathrm{~m}^{3} / \mathrm{s}$ and water used for irrigation ranged between 0.01 and $1.8 \mathrm{~m}^{3} / \mathrm{s}$. The sub-basins with the highest streamflow were those that presented the highest domestic consumption of water and the largest amount of water spent in irrigation. The highest water consumption was recorded in the sub-basins located in west of the basin. The low domestic consumption of water is due to the low population density and the low water consumption per capita (Fig. 2, Table 1). For example, the year 2005, the population density registered was 20.4 inhabitants $/ \mathrm{km}^{2}$. Each inhabitant consumed on average 49 liters/day of water, which implies a negligible decrease of $0.03 \%$ in the streamflow, while in the summer period the decrease rises to $1.4 \%$, due to immigration. On the other hand, the water consumption for irrigation was more significant. The basin has approximately 573 hectares of irrigated area [9], which represents $18 \%$ of the basin area (Table 1). The highest water consumption occurred in west of the basin, where olive, fruit trees and vegetables and legumes dominate (Fig. 2). The water used for irrigation represented, on average, $27 \%$ of the streamflow of the basin, between 1960 and 2009 .

Figs 5(d)-(f) show the average values of projections of streamflow and water used for domestic consumption and irrigation for 2060 . The decline of $24 \%$ of the population will

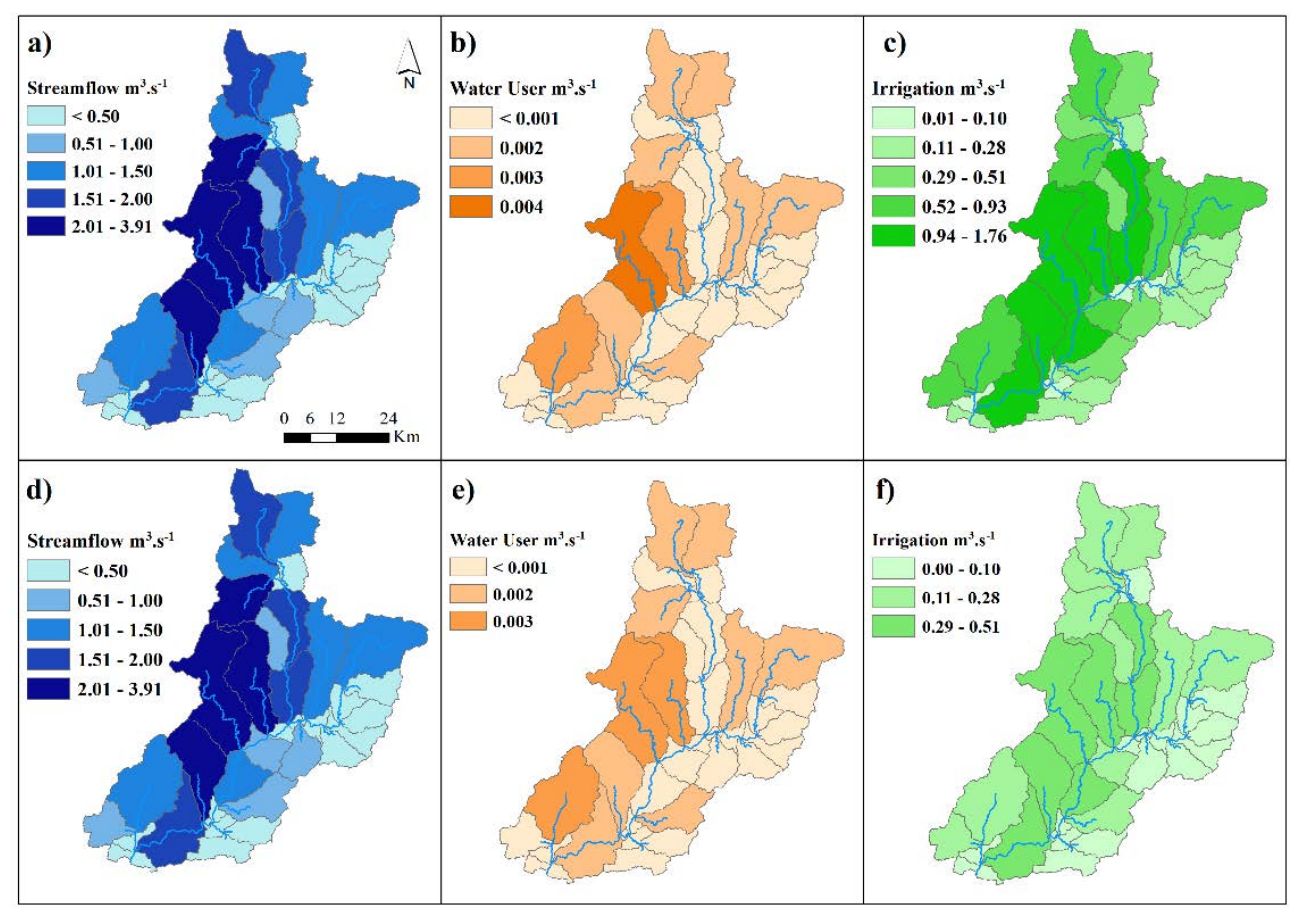

Figure 5: (a), (d) Spatial distributions of streamflow; (b), (e) Water used for domestic consumption; (c), (f) Water used for irrigation at the Sabor River sub-basin scale. The figures (a), (b) and (c) represent the spatial distributions of measured data between 1960 and 2009 and the figures (d), (e) and (f) represent the projections of streamflow, water user and irrigation for 2060. 
lead to a decrease in the use of water for domestic consumption. This decrease will have little impact on the availability of water in the basin because the population density is low. However, the reduction of $71 \%$ of the irrigable area, as a consequence of agricultural abandonment, will lead to increased availability of water in the basin. The sub-basins most affected with the reduction of the irrigable area are situated in west of the basin, where agricultural production is greatest.

\section{CONCLUSIONS}

This study used two water modelling software packages, SWAT and MIKE HYDRO Basin. SWAT was used to model the components of the water balance and MIKE HYDRO Basin, the simulation of water allocation, namely irrigation and domestic consumption. The comparison between simulated and observed streamflow showed that the SWAT underestimated the observed streamflow, but the coefficient of determination was reasonable (0.7). Although the software has shown some difficulty in representing the peak events. The study concluded that the low population density, recorded in the basin area, did not have a significant impact on the streamflow. On the other hand, irrigation represented a consumption of $27 \%$ of the streamflow, that was used to irrigate $18 \%$ of the irrigated area of the basin. It is expected that the change in agricultural practices will have impact on the quantity and quality of the basin water resources. The demographic projection and the irrigable area projection for 2060 estimate the population reduction of $24 \%$ and the irrigation reduction of $71 \%$. The water consumption percentage for domestic use will be very small and the water used in irrigation will be decreased significantly as a consequence of population decline and agricultural abandonment.

\section{ACKNOWLEDGEMENTS}

This work is financed by: INTERACT project - "Integrative Research in Environment, Agro-Chains and Technology", No. NORTE-01-0145-FEDER-000017, in its line of research entitled ISAC-P2, co-financed by the European Regional Development Fund (ERDF) through NORTE 2020 (North Regional Operational Program 2014/2020).

\section{REFERENCES}

[1] Neitsch, S.L., Arnold, J.G., Kiniry, J.R. \& Williams, J.R., Soil and Water Assessment Tool Theoretical Documentation Version 2009. Grassland, Soil and Water Research Laboratory, Blackland Research Center: Temple, Texas, USA, 2011.

[2] Arnold, J.G. et al., SWAT: Model use, calibration, and validation. Trans. ASABE, 55(4), pp. 1491-1508, 2012.

[3] Neupane, R.P. \& Kumar, S., Estimating the effects of potential climate and land use changes on hydrologic processes of a large agriculture dominated watershed. Journal of Hydrology, 529, pp. 418-429, 2015.

[4] Rocha, J., Roebeling, P. \& Rial-Rivas, M.E., Assessing the impacts of sustainable agricultural practices for water quality improvements in the Vouga catchment (Portugal) using the SWAT model. Science of The Total Environment, 536, pp. 48-58, 2015.

[5] DHI - MIKE HYDRO Basin water quality model. Water and Environment. Danish Hydraulic Institute, Hørsholm, Online. www.dhigroup.com/. Accessed on: 13 Nov. 2017.

[6] Bangash, R.F., Passuello, A., Hammond, M. \& Schuhmacher, M., Water allocation assessment in low flow river under data scarce conditions: A study of hydrological 
simulation in Mediterranean basin. Science of the Total Environment, 440, pp. 60-71, 2012.

[7] Santos, R.M.B., Fernandes, L.S., Pereira, M.G., Cortes, R.M.V. \& Pacheco, F.A.L., Water resources planning for a river basin with recurrent wildfires. Science of the Total Environment, 526, pp. 1-13, 2015.

[8] DGT - Direção-Geral do Território, Online. www.dgterritorio.pt/. Accessed on: 13 Nov. 2017.

[9] EEA - European Environment Agency, Online. www.eea.europa.eu/. Accessed on: 13 Nov. 2017.

[10] SNIRH - Sistema Nacional de Informação de Recursos Hídricos, Online. http://snirh.apambiente.pt/. Accessed on: 13 Nov. 2017.

[11] INE - Base de dados online do site do Instituto Nacional de Estatística, Online. www.ine.pt/. Accessed on: 23 Nov. 2017.

[12] PORDATA - Base de dados Portugal contemporâneo, Online. www.pordata.pt/. Accessed on: 23 Nov. 2017.

[13] Allen, R.G., Pereira, L.S., Raes, D. \& Smith, M., FAO Irrigation and drainage paper No. 56, Food and Agriculture Organization of the United Nations: Rome, 56(97), 1998.

[14] Carvalho, A., Recenseamento Agrícola 2009: Análise dos Principiais Resultados. INE - Instituto Nacional de Estatística, edição, 2011.

[15] DGADR, Estratégia para o regadio público 2014-2020. Technical Report. Direção Geral da Agricultura e Desenvolvimento Rural, 2014. 